\title{
IUELTAL
}

\section{EFL Students' English Language Development: In Participation of International Exchange Program}

\author{
Ariyanti \\ University of Widya Gama Mahakam Samarinda \\ e-mail:ariyanti.muflihin@gmail.com
}

\begin{abstract}
:
This research is aimed to investigate students development in terms of their English speaking proficiency, vocabulary and pronunciation aspects in context of English as Foreign Language. Furthermore, six EFL students who become subject of this research are Indonesian students who are originally stil studying at University of Widya Gama Mahakam Samarinda, Indonesia. In this case, those students had an experience of participating an international program what so called by Sea-Teacher, one of priority programs under Southeast Asian Ministers of Education (SEAMEO) which its homebase is in Bangkok, Thailand. Moreover, in dept interview was applied to those six students in order to find out what sort of effects they acquire after participating the Sea-Teacher program. As a result, all of exchange students experience development in terms of their oral proficiency, vocabulary as well as pronunciation. Natural condition in using English as language of communication was formed when conversing with local people and teaching in classrooms. Research implication and suggestion are also noticed in this study.
\end{abstract}

Keywords: English language development, Exchange students, international programs, oral proficiency, Sea-Teacher program

\section{Introduction}

Learning English is no longer applying in old fashion just like in classroom. The framework of learning languages is already set in wider perspectives, where students especially in context of English as a Foreign Language can experience studying abroad while learning target language. It is beneficial for students who are eager to advance their cabalities in mastering English by accessing the target language environment inherently (Gautier \& Chevrot, 2015). For many years, international programs for students become very fascinated for students as well as very interesting area in terms of language and adjustment in academic context 
(Vasilopoulos, 2016). International exchange programs are a result of globalization era where people have linkage in terms of cultures and information sharing among many countries (GÜRLEK, 2016).

Nowadays, international programs for students are spread out in many countries including Indonesia. Many universities promote international exchange program on their curriculum or optional for students to choose (Asli, Sadikin, \& Le, 2017). Higher education institutions provide opportunities for their students to experience sort of international programs to compete with globalization. It is because by participating in such programs, students can escape from their narrow borders and go further on multiculturalism and meet people globaly as well as gaining new knowledge (Green, LuU, \& Burris, 2008). A developed country such as Britain even has "British year abroad" where it is a requirement for students to take at least two semesters to participate sort of international immersion programs (Mitchell, McManus, \& Tracy-Ventura, 2015). It showed that many higher education institutions in developing and developed countries assumed that international programs is positive and valuable for students to gain different angle of learning new language (Dewaele, Comanaru, \& Faraco, 2015). Students can find many information regarding with how to participate in an international program and join the program by their own efforts, or university may have partnership with formal institution overseas. This activity becomes very familiar at the present time where students can develop their English proficiency in many parts such as speaking ability, grammar, and writing (Pinar, 2016). Communication skill of students who join an international exchange program surely will be well-developed (Gargano, 2012). It is assumed that studying abroad or participating international programs is an effective path to gain language capabilities especially in speaking (Silvio, Malone, \& Donovan, 2014 ; 2015). By learning a new language abroad, students will learn how to practice their English speaking in appropriate context (Juan-Garau, 2015). It is significant element in studying a new language because to speak in centain context might be different from another context of talk. Therefore, naturally, students will learn and understand how to speak in certain context of talk directly at a country where English is spoken (Taguchi, 2018).

There are many studies related to study abroad for students and teaching overseas experiences for teachers. For example, a research from Serin (2017) where he explored sort of benefits that teachers can get when they have experiences in teaching abroad. In line with Serin (2017), Radhakrishna \& Ingram (2004) also analyse many advantages that students are able to obtain during and after program of students' exchange. Because of many advantages that exchange students gain, it is suggested that the longer international program is held, the more significant their academic and cultural development (Dwyer, 2004). Indeed, participating international programs such as studying abroad or exchange programs will affect to students' language development. In this case, a research from Isabelli-Garcıa et al. (2018) observed concerning with students' English language skills developed by participating an international program. It is very fascinating since learning out of university context becomes one of learning trends where the target language is different with students' L1 (Isabelli-Garcıa et al., 2018).

Above facts lead the researcher to deep curiousity to analyse how far and in what part of English language proficiency that EFL students can develop after joining an international program in the case of linguistics, speaking skill, pronunciation, grammar, lexical, and writing competences (Pinar, 2016). Specifically, this study was observed and focused only to 
three elements which are connected one to another i.e. oral proficiency, pronunciation, and vocabulary acquisition. As the intention of the international exchange program joined by subject in this research is to have exchange student teachers experience teaching English overseas, this study also described whether their teaching skill is improved.

\section{Literature Review}

Combining teaching and learning in classrooms with internationalization is a central element to be included in curriculum nowadays as it has high impact on educational outcomes (Costa, 2018). There are many advantages that students can acquire by studying abroad or joining a kind of international program. As proposed by Victoria State Government (2015) that there are at least two sides of benefits that the students can obtain when participating an international activity, they are personal competence and intercultural knowledge. Personal competence, in this case, brought to larger meaning where the students can enhance their self-confidence and maturity. In addition, the students can stand out of their confort zone where they should learn how live and survive the very different environment and see everything from different angel. This personal competence point also provide the students with readiness on viewing future working opportunities so they will not left behind and be able to take part in this developed working sites. In short, not only a prospect to travel overseas and international degrees, international exchange programs also offer chances to have working experiences or even permanent employment abroad (Gargano, 2012).

Not only personal competence, intercultural knowledge is also precious aspect that the students can gain through experiences of studying abroad (Victoria State Government, 2015). For instance, it will be beneficial part in larger point of view when comparing stereotypes in own country and overseas as well as opening students' ways of thinking towards international issues happening lately. Furthermore, studying abroad drives the students to awareness of cultural diversities and employ appreciateness action. Intercultural point also valuable for students in terms of motivation in learning as well as motivation in gaining better future such as job oportunities. It is because by involving to certain exchange program, students are able to develop the essence of attentiveness and gratefulness toward cultural assortment where at the same time they can grow personal attitudes and skills so that they can be an independent personality and become successful in real world (Zhai \& Scheer, 2002). As an appreciation of multicultural environment is the central matter (GÜRLEK, 2016), therefore, it is highly important to notice that a teacher must integrate the essense of cultural sensitivity in teaching as it is one of factors to result desirable students' learning outcomes (Ference \& Bell, 2004).

Another benefit that students can obtain from an exchange program is experiences of adapting new knowledge and culture. This process of adaptation is highly possible to give students a chance on increasing students' learning ability (Asli et al., 2017). Global interaction with new people in new countries indeed lead students to learn an aspect of multiculturalism as well as new knowledge which does not exist in their own country (Green et al., 2008).

Other than that, in context of learning language, students can have chances of learning another language. As pointed out by Radhakrishna \& Ingram (2004) that an exchange program will promote a learning of a foreign language for EFL students. In addition, the 
students also will be aided on acquiring a foreign language because they learn naturally by communicating to surrounding native speakers. Students will be very close to have connection with target language and have a practice on mastering it especially with host family where international students will have a perfect arrangement on performing their oral proficiency (Silvio et al., 2014; 2015).

\section{Research Methodology}

This research is a case study where the researcher will interview seven students who participated in International Program named Sea-Teacher. Sea-Teacher is pre-service program for student-teachers to have teaching practice at overseas school starting from elementary, junior, and senior high levels. In addition, the program gives students of university especially whose background are from Teacher Training and Education Faculty an opportunity to learn and have a directly teaching practicum at an international school in ASEAN context. The program is held for one month which consisting of orientation and class observation, teaching assistant, teaching in classroom, and reflection.

Specifically, the interview will chase on the impacts that EFL students obtain after joining Sea-Teacher program. In this case, the researcher relies on theory proposed by Pinar (2016) which consist of six elements which become effects when someone is having experiences on studying overseas, they are effects on linguistic knowledge, oral proficiency, pronunciation, grammatical knowledge, lexical knowledge, and writing abilities. Among those six elements proposed by Pinar (2016), the researcher only focuses on exchange students' oral proficiency, pronunciation, and vocabulary since those three aspects are related one to another. In addition, students' learning attitude toward learning speaking in new country was also observed to gain additional data to support the main one. Other than that, there was another aspect that investigated by the researcher i.e. teaching skills in. Since the main objective of Sea-teacher program is to enhance student-teacher teaching skill, and additionally those exchange students are from Teaching English Department, the researcher believe that it is a must to explore how the exchange students feel about their teaching skill which practiced overseas.

Moreover, the data was collected and analysed by relying on theory from Cresswell (2003) where there are mainly three steps including data gathering and memoing, data reduction and classification, and conclusion. Specifically, interview was transcribed, coding, classified, and reduced in order for the researcher to gain the intened data. Finally, the data interpreted as well as compated to existing theories and previous studies.

\section{Findings}

Having analyzing the interview transcript from six interviewees, the researchers found several facts about how pre-service students view the Sea-Teacher program and what benefits they obtained. It is also important to note that two of six students had experienced joining in international student exchange program meanwhile the other four had not.

First of all, all of students have fully awareness and are acknowledged well about the SeaTeacher program and what objectives they need to reach during the program. All students stated that the Sea-Teacher program is held by SEAMEO in cooperation with particular universities in Southeast Asia country such as Philippines, Malaysia, Indonesia, Singapore, etc. This program allows undergraduate students from teacher training program to 
participate in international student exchange to teach in the chosen country managed by the university who also participated in this program. Most of students noticed that this program would enhance their teaching skill, since it is the main objective of Sea-Teacher program, and gain teaching experience overseas. Few students expect to improve their public speaking skill.

Regarding to students' reasons joining the sea-teacher program, there are four points they expected to achieve during and after the program carried out; 1 ) improving teaching skill, 2) improving English language skill, 3) gaining intercultural knowledge, and 4) widening their horizon. First, related to teaching skill, most of students expected to gain teaching experience $(67 \%)$ and enhance teaching skill (33\%). Meanwhile, other students hoped to improve their English language skill, especially speaking (50\%) and public speaking skill $(17 \%)$. However, to widen their horizon, students expected to gain more knowledge $(50 \%)$, gain more experience $(17 \%)$, and to learn different education system in other countries. Considering the reasons they mentioned, it shows that the pre-service students have met the Sea-Teacher program's objectives.

The students were also excited involving in this international student exchange program. In terms of teaching skill, this program provides useful experience to be a professional teacher (Student 1). Student 2 said it was her first opportunity to teach overseas. Other students feel excited since they can have fun in teaching (Student 4 ) and got the best teaching experience (Student 6). Similarly, student 5 felt this program helped her to increase her motivation and creativity in teaching. Regarding to English skill, students are motivated to join the program since they can apply their English skill and knowledge in real life (student 3) and improve their English speaking skill (student 5).

The above paragraphs have displayed and described the importance and the benefits of joining international program from the view of students who took part in Sea-Teacher program. Reflecting their previous condition, students admitted that their English proficiency was away from good before joining the program. They had limited English vocabularies (50\%), were not confident to speak English (33\%), and had poor English proficiency (17\%). However, after joining the program, they found their English proficiency has improved $(83 \%)$. They stated they had gone through some process that made their English skill better especially for speaking skill (17\%). During the program, they were forced to speak in English with their buddies, mentors, teachers, society, even taxi drivers (17\%). They also admitted that their vocabulary range become wider (33\%) and become more confident to speak in English (50\%).

Dealing with learning attitude relate to speaking competencies, before joining the program, students stated that they were lazy to read English books (student 2) and lack of communication in English (student 3). However, students said that their learning attitude was okay (student 4) and were serious learner (student 6). Other student was satisfied with his current achievement (student 1). During and after the Sea-Teacher program, the interviewees felt that their learning attitude improved. They felt motivated to learn more especially for enhancing their vocabulary and becoming fluent in speaking English (student 1 and student 5), to read and love more books (student 2), to change their mindset about setting life purpose through learning hard process (student 3), and to be more considerate to students they teach (student 4 ). 
Moreover, the international student exchange program brings some positive effects to students' English language acquisition especially in speaking. Surely they can acquire English better since during the program they had a lot of buddies to talk with (student 1), so they managed to understand and communicate in English and produce simple English words to explain things (student 2 and 3). In addition, they felt more tolerable and confident when communicating in English (student 3). They developed their pronunciation through studying and practicing them with their mentor before teaching (student 2 and 5), listening to mentors' and other students' pronunciation, and communicating in English every day (student 6). They are aware that having clear pronunciation will lead to clear explanation when they teach (student 1 and 4 ).

To make it easier to depict, the following table will locate and summarize their answers and the researcher put them in percentages. Still, since it is qualitative approach, the percentage is only for general view but the explanation should be the main data and analysis.

\section{Table 1. Data Display of Interview}

\begin{tabular}{|c|c|c|c|}
\hline No & Questions & Interviewee's answers & Percentages \\
\hline 1 & $\begin{array}{l}\text { Do you know what Sea- } \\
\text { Teacher program is? }\end{array}$ & $\begin{array}{l}\text { Yes. It is a program held by SEAMEO for student } \\
\text { teacher with purpose; } \\
\text { 1) To enhance teaching skill } \\
\text { 2) To gain teaching experience overseas } \\
\text { 3) To improve public speaking } \\
\text { 4) To learn about other culture }\end{array}$ & $\begin{array}{l}100 \% \\
50 \%\left(S_{1}, S_{3}, S 6\right) \\
33 \%\left(S_{2}, S_{4}\right) \\
33 \%\left(S_{3}, S_{6}\right) \\
17 \%\left(S_{6}\right)\end{array}$ \\
\hline 2 & $\begin{array}{l}\text { Why do you join the Sea- } \\
\text { Teacher program? }\end{array}$ & $\begin{array}{l}\text { 1) To enhance teaching skill } \\
\text { 2) To gain teaching experience } \\
\text { 3) To improve English skill, especially } \\
\text { speaking skill } \\
\text { 4) To experience and to know other culture } \\
\text { 5) To improve public speaking skill } \\
\text { 6) To learn different education system } \\
\text { 7) To gain more knowledge } \\
\text { 8) To gain more experience }\end{array}$ & $\begin{array}{l}33 \%\left(\mathrm{~S}_{1}, \mathrm{~S}_{3}\right) \\
67 \%\left(\mathrm{~S}_{2}, \mathrm{~S}_{4}, \mathrm{~S}_{5}, \mathrm{~S}_{5}\right) \\
50 \%\left(\mathrm{~S}_{1}, \mathrm{~S}_{2}, \mathrm{~S}_{3}\right) \\
33 \%\left(\mathrm{~S}_{1}, \mathrm{~S}_{2}\right) \\
17 \%\left(\mathrm{~S}_{3}\right) \\
17 \%\left(\mathrm{~S}_{3}\right) \\
50 \%\left(\mathrm{~S}_{3}, \mathrm{~S}_{5}, \mathrm{~S}_{6}\right) \\
17 \%\left(\mathrm{~S}_{3}\right)\end{array}$ \\
\hline 3 & $\begin{array}{l}\text { Are you excited on } \\
\text { joining Sea-Teacher } \\
\text { program? Please explain! }\end{array}$ & $\begin{array}{l}\text { Yes. For three reasons: } \\
\text { 1) Teaching skill: } \\
\circ \quad \text { Got useful experience to be a professional } \\
\text { teacher } \\
\circ \quad \text { First opportunity to teach English overseas } \\
\circ \quad \text { Have fun in teaching } \\
\circ \quad \text { Helps to increase motivation and creativity } \\
\text { in teaching } \\
\circ \quad \text { Get best teaching experience } \\
\text { 2) English skill: } \\
\text { Applied English in real life as a second } \\
\text { language } \\
\text { Improve English speaking skill }\end{array}$ & $\begin{array}{l}100 \% \\
17 \%\left(\mathrm{~S}_{1}\right) \\
17 \%\left(\mathrm{~S}_{2}\right) \\
17 \%\left(\mathrm{~S}_{4}\right) \\
17 \%\left(\mathrm{~S}_{5}\right) \\
17 \%\left(\mathrm{~S}_{6}\right) \\
17 \%\left(\mathrm{~S}_{3}\right) \\
17 \%\left(\mathrm{~S}_{5}\right)\end{array}$ \\
\hline 4 & $\begin{array}{l}\text { How do you feel your } \\
\text { English speaking } \\
\text { proficiency before joining } \\
\text { Sea-Teacher program? }\end{array}$ & $\begin{array}{l}\text { 1) Limited vocabulary } \\
\text { 2) Not confident to speak English } \\
\text { 3) Good enough } \\
\text { 4) Not sure, pretty bad } \\
\text { 5) Not answered }\end{array}$ & $\begin{array}{l}50 \%\left(\mathrm{~S}_{1}, \mathrm{~S}_{2}, \mathrm{~S}_{3}\right) \\
33 \%\left(\mathrm{~S}_{2}, \mathrm{~S}_{3}\right) \\
17 \%\left(\mathrm{~S}_{4}\right) \\
17 \%\left(\mathrm{~S}_{5}\right) \\
17 \%\left(\mathrm{~S}_{6}\right)\end{array}$ \\
\hline 5 & How is your learning & Satisfy with current achievement & $17 \%\left(S_{1}\right)$ \\
\hline
\end{tabular}




\begin{tabular}{|c|c|c|c|}
\hline No & Questions & Interviewee's answers & Percentages \\
\hline & $\begin{array}{l}\text { attitude before joining } \\
\text { Sea-Teacher program? }\end{array}$ & $\begin{array}{l}\text { 2) Lazy to read English books } \\
\text { 3) Lack of communication in English } \\
\text { 4) Good } \\
\text { 5) Serious learner } \\
\text { 6) Not answered } \\
\end{array}$ & $\begin{array}{l}17 \%\left(\mathrm{~S}_{2}\right) \\
17 \%\left(\mathrm{~S}_{3}\right) \\
17 \%\left(\mathrm{~S}_{4}\right) \\
17 \%\left(\mathrm{~S}_{5}\right) \\
17 \%(\mathrm{~S}) \\
\end{array}$ \\
\hline 6 & $\begin{array}{l}\text { Do you feel you have } \\
\text { improvement on your } \\
\text { English speaking } \\
\text { acquisition after joining } \\
\text { Sea-Teacher program? }\end{array}$ & $\begin{array}{l}\text { Yes. } \\
\text { It improves because some reasons; } \\
\text { 1) Students have a lot of buddies to talk } \\
\text { with in English } \\
\text { 2) Students manage to understand and } \\
\text { communicate in English } \\
\text { 3) Students produce and use simple words } \\
\text { to explain things in English } \\
\text { 4) Students feel more tolerable and } \\
\text { confident when communicating in } \\
\text { English Students learn how to speak in simple } \\
\text { 5) English so it is easier to understand }\end{array}$ & $\begin{array}{l}100 \% \\
17 \%\left(\mathrm{~S}_{1}\right) \\
17 \%\left(\mathrm{~S}_{2}\right) \\
17 \%\left(\mathrm{~S}_{2}\right) \\
17 \%\left(\mathrm{~S}_{3}\right) \\
17 \%\left(\mathrm{~S}_{3}\right)\end{array}$ \\
\hline 7 & $\begin{array}{l}\text { Do you feel by joining } \\
\text { Sea-Teacher program } \\
\text { can affect your oral } \\
\text { proficiency? Please } \\
\text { explain! }\end{array}$ & $\begin{array}{l}\text { Yes, through the following conditions: } \\
\text { 1) students talk a lot to buddies and } \\
\text { lecturers also had discussion such as } \\
\text { making lesson plan, making power point } \\
\text { presentation, and talking about culture } \\
\text { 2) } \\
\text { discussionts had long conversation or formal } \\
\text { plans and other things } \\
\text { student teachers always talk to buddies, } \\
\text { mentor, and other their students } \\
\text { 4) when student teacher learn their culture } \\
\text { and they cannot speak random English to } \\
\text { them they need to speak something right } \\
\text { so it doesn't result miscommunication } \\
\text { 5) Student teacher must speak in English in } \\
\text { teacher and when to communicate to } \\
\text { their students. } \\
\text { 6) after got demo teaching } \\
\text { In brief, students can improve their oral } \\
\text { proficiency as the result of full exposure from } \\
\text { people surrounding who always speak English as } \\
\text { the tool of communication }\end{array}$ & $\begin{array}{l}100 \% \\
17 \%\left(S_{1}\right) \\
17 \%\left(S_{2}\right) \\
17 \%\left(S_{3}\right) \\
17 \%\left(S_{4}\right) \\
17 \%\left(S_{5}\right) \\
17 \%\left(S_{6}\right)\end{array}$ \\
\hline 8 & $\begin{array}{l}\text { Do you feel by joining } \\
\text { Sea-Teacher program } \\
\text { can affect your } \\
\text { pronunciation? Please } \\
\text { explain! }\end{array}$ & $\begin{array}{l}\text { Yes } \\
\text { 1) clear pronunciation make teacher's } \\
\text { explanation understandable } \\
\text { 2) students always practice and check } \\
\text { pronunciation with mentor before } \\
\text { teaching } \\
\text { 3) improved by hearing mentor's and } \\
\text { students' pronunciation } \\
\text { 4) students study to improve pronunciation } \\
\text { 5) students are forced to use English every } \\
\text { day to communicate }\end{array}$ & $\begin{array}{l}100 \% \\
33 \%\left(\mathrm{~S}_{1}, \mathrm{~S}_{4}\right) \\
17 \%\left(\mathrm{~S}_{2}\right) \\
17 \%\left(\mathrm{~S}_{3}\right) \\
17 \%\left(\mathrm{~S}_{5}\right) \\
17 \%\left(\mathrm{~S}_{6}\right)\end{array}$ \\
\hline 9 & $\begin{array}{l}\text { Do you feel by joining } \\
\text { Sea-Teacher program }\end{array}$ & Yes & $83 \%$ \\
\hline
\end{tabular}




\begin{tabular}{|c|c|c|c|}
\hline No & Questions & Interviewee's answers & Percentages \\
\hline & $\begin{array}{l}\text { can affect your } \\
\text { vocabulary? Please } \\
\text { explain! }\end{array}$ & $\begin{array}{l}\text { 1) have variety of vocabularies to convey } \\
\text { opinion } \\
\text { 2) through reading book when preparing } \\
\text { teaching } \\
\text { 3) through listening to people talking } \\
\text { 4) learn more vocabulary to teach better } \\
\text { 5) through conversation and discussion with } \\
\text { buddies, teachers, mentors }\end{array}$ & $\begin{array}{l}17 \%\left(\mathrm{~S}_{1}\right) \\
17 \%\left(\mathrm{~S}_{2}\right) \\
17 \%\left(\mathrm{~S}_{3}\right) \\
17 \%\left(\mathrm{~S}_{5}\right) \\
17 \%\left(\mathrm{~S}_{6}\right)\end{array}$ \\
\hline
\end{tabular}

\section{Discussion}

Joining international exchange program surely brings positive effects to students who actively involved. The six interviewees are aware of the objectives of the program therefore they are excited to participate in Sea-Teacher program. All of students acknowledge that Sea teacher program is held by SEAMEO only for pre service teachers who eager to improve their teaching skill ; have teaching experience in other countries, especially Southeast Asia; and improve their English speaking skill. These objectives meet their main reasons to join the program, precisely on three aspects; 1) improving English speaking skill, 2) gaining more teaching experiences, and 3) learning cultural diversity. Some students admitted that through the program they intended to practice their speaking and become fluent as well as to develop their public speaking skill. Moreover, since it is internship for teaching program, most of students expected to gain more experiences in teaching students from overseas in which English as second language for them, to acquire more knowledge in pedagogy and to encourage themselves to be teach actively. For other reasons, related to intercultural knowledge, most students also aimed to experience other culture that make them aware of cultural diversity and learn to survive in a place where it has high range of diversity in terms of culture, people, language, and education system.

The interviewees were really excited joining the Sea-Teacher program for some important reasons. First, they wanted to learn to be a professional English teacher by participating in teaching program from the preparation such as making lesson plans, to the teaching practice. During the teaching activities, they expected to learn how to create fun and creative teaching which would increase their motivation and leave best teaching experiences. Regarding to English speaking skill, they are challenged to use English all the time during the program and survive since it is the only language that can they use for communication. It can be said that the Sea-Teacher program has made improvement on English speaking, vocabulary and pronunciation (Pinar, 2016; Serin, 2017; (Silvio et al., 2014 \& 2015). It also confirms the study from Isabelli-Garcia et al. (2018) stated that among writing, readinh, and listening skills, speaking is the most result gained from studying abroad and paricipating sort of internatioanl exchnage programs. Students are well developed significantly on their oral proficiency rather than other English language acquisition elements.

As it stated above, the program also helps students to improve their English skill. Students noticed that before participating in sea-teacher program, their English proficiency are considerably poor, in terms of limited vocabulary and confidence in speaking. During and after the program, they realized that their English skill becomes better and increases. Their speaking skill has improved and managed to use various vocabularies to express and deliver 
their ideas and opinion. Their self-confidence also has boosted since they are forced to use English to communicate and survive. Regarding to their learning attitude, they admitted that, before joining the program, they have pretty bad attitude. They were lazy to read books, especially English literatures. They were not serious in learning English. This program has made them realize the importance of learning well and improved their learning attitude. This program makes them realize that it is important to learn seriously and not be lazy to upgrade their English skill, especially in enriching their vocabulary through reading more books, communicate more in English to people from overseas and encourage themselves to always have learning motivation.

Having joining the Sea-Teacher program, they admitted some improvement they gained especially on their English language acquisition and proficiency. They stated that, they acquire English better through buddies they have during the program. What is more, they also have to communicate well in English and from the process, they learnt how to simply speak in English by using simple words. The people are also tolerable and encourage the students to be more confident to communicate in English. The students also recognize the improvement they have made during and after the program. Their English speaking skill improved faster since they have to talk in English to their buddies, teachers, people around them, even to taxi driver. They were also involved in discussion with teachers and students, making presentations and lesson plans. Their friends during the program are some from many countries too, such the USA, the UK, China, Singapore, etc. This condition makes students forced to use English all the time to survive, so that, their English also improved.

In addition, that condition also contributed to their vocabulary range which become larger and boost their confidence. They learnt variety of English vocabulary through books that they had to read during the program to prepare the teaching, and when they talked to overseas students; they gained new vocabulary during communication with people in school they teach or places they visited. It is true because having international programs participated is a perfect learning context (Juan-Garau, 2015).

Not only speaking skill and vocabulary improved, their pronunciation also well developed. They realized that the importance of clear pronunciation when teaching, i.e. to make students understand their explanation clearer and when communicate, in order to avoid misunderstanding. Therefore, they seriously learned how to pronounce English words correctly. They were also exposed to and got direct examples of English words pronounced although with different accents. Similar to Grammatical knowledge, they also learnt how to use correct grammar in communication and teaching, for avoiding and lessening misunderstanding.

Above all, future implication proposed in this research is focused on not only EFL students' capability in English language proficiency, but their experiences on studying above no matter what program that is will result a clearer idea on what carrier goals that they would like to achieve for their future (Hannigan, 2018). Therefore, pre-departure orientation before application of any study abroad program should drive students to realize and think this important goal so that they can be encouraged to reach successful life by connecting their English language proficiency and their target of future carriers. 


\section{Conclusion}

Above findings and discussion indicate that most of exchange students feel that there their oral proficiency was improved after joining the Sea-Teacher program. They gained their improvement in speaking skill in two situation i.e. when communicating to local people and when teaching in classrooms. In accordance with the improvement of their oral proficiency, their vocabulary and pronunciation were also improved because they are urged in using English with local people who only speak their vernacular language and English. They were placed in natural condition where they met people who will only understand English as the language of communication. From many benefits that the exchange students gained, it implies the urgency of involving students in joining such international program since it will support their soft skill especially in English speaking proficiency where it is needed for their future. Some of the subjects as international exchange students continuously and actively experience on joining other international programs after Sea-Teacher program finished. More support from universities is acquired to facilitate other students who eager to participate in other international programs.

\section{References}

Asli, U. A., Sadikin, A. N., \& Le, C. D. (2017). A Study on the Impact of International Academic Visit Exchange Programme among Chemical Engineering Students. Chemical Engineering Transactions, 56, 1093-1098.

Costa, G. dos S. (2018). Language \& Culture in English as a Foreign Language Teaching: a Socio-cultural Experience of Some Exchange Students from Piauí Federal Institute. Araraquara, 13(1), 379-390.

Cresswell, J. W. (2003). Research Design, Qualitative, Quantitative, and Mixed Method Approach (2nd ed.). California: Sage Publications.

Dewaele, J.-M., Comanaru, R.-S., \& Faraco, M. (2015). The Affective Benefits of a Presessional Course at the Start of Study Abroad (R. Mitchell, N. Tracy-Ventura, \& K. McManus, eds.). Amsterdam: The European Second Language Association.

Dwyer, M. M. (2004). More Is Better: The Impact of Study Abroad Program Duration. Frontiers: The Interdisciplinary Journal of Study Abroad, 10, 151-163.

Ference, R., \& Bell, S. (2004). A cross-cultural Immersion in the U.S.: Changing Preservice Teachers Attitudes toward Latino ESOL Students. Equity and Excellence in Education, $37(4), 343-35$.

Gargano, T. (2012). Grounded Identities, Transient Lives: The Emergence of International Student Voices in an Era of Cosmopolitan Learning. Journal of International Students, 2, 144-157.

Gautier, R., \& Chevrot, J.-P. (2015). Social Networks and Acquisition of Sociolinguistic Variation in a Study Abroad Context: A Preliminary Study (R. Mitchell, N. Tracy-Ventura, \& K. McManus, eds.). Amsterdam: The European Second Language Association.

Green, M. F., LuU, D., \& Burris, B. (2008). Mapping Internationalization on U.S. Campuses. Washington, DC: American Council on Education.

GÜRLEK, A. (2016). The Effect of Erasmus Exchange Program on Attitudes towards Learning English Foreign Language. International Journal of Languages' Education and Teaching, 4(1), 18-32.

Hannigan, T. P. (2018). Collaboration Between International Education and Career 
Development Professionals to Improve the Quality and Impact of Work Abroad Experiences. In M. Tillman (Ed.), Impact of Education Abroad on Career Development (Vol. 1). Stamford: American Institute For Foreign Study.

Isabelli-Garcia, C., Bown, J., Plews, J. L., \& Dewey, D. P. (2018). Language Learning and Study Abroad. Lang. Teach., 51(4), 439-484.

Juan-Garau, M. (2015). Speaking an Additional Language: Can Study Abroad Do the Trick? Language Value, 7(1), 46-61.

Mitchell, R., McManus, K., \& Tracy-Ventura, N. (2015). Placement Type and Language Learning During Residence Abroad (R. Mitchell, N. Tracy-Ventura, \& K. McManus, eds.). Amsterdam: he European Second Language Association.

Pinar, A. (2016). Second Language Acquisition in a Study Abroad Context: Findings and Research Directions. Colomb. Appl. Linguist. Journal, 8(2).

Radhakrishna, R. B., \& Ingram, P. D. (2004). Evaluating the Impact of 4-H Japanese Exchange Program. Proceedings of the 2oth Annual Conference of AIAEE. Dublin, Ireland: AIAEE.

Serin, H. (2017). The Effects of Teaching Abroad on Personal and Professional Development. International Journal of Social Sciences \& Educational Studies, 4(1).

Silvio, F. Di, Donovan, A., \& Malone, M. (2015). Promoting Oral Proficiency Gains in Study Abroad Homestay Placements (R. Mitchel, N. Tracy-Ventura, \& K. McManus, eds.). Amsterdam: The European Second Language Association.

Silvio, F. Di, Malone, M. E., \& Donovan, A. (2014). The Effect of Study Abroad Homestay Placements: Participant Perspectives and Oral Proficiency Gains. Foreign Language Annals, 47(1).

Taguchi, N. (2018). Contexts and Pragmatics Learning: Problems and Opportunities of the Study Abroad Research. Lang. Teach., 51(1), 124-137.

Vasilopoulos, G. (2016). A Critical Review of International Students' Adjustment Research from a Deleuzian Perspective. Journal of International Students, 6(1), 283-307.

Victoria State Government. (2015). Oversea Learning Experiences for Students: A Resource for Schools. Victoria: International Education Division of School Education Group.

Zhai, L., \& Scheer, S. D. (2002). Influence of International Study Abroad Programs on Agricultural College Students. Journal of International Agricultural and Extension Education, 9(3), 23-29. 